\title{
Eksistensi Tradisi Mangupa Batak Mandailing di Kelurahan Yukum Jaya Lampung Tengah
}

\author{
Ali Imron ${ }^{\mathrm{a}, 1}$, Yusuf Perdana ${ }^{\mathrm{b}, 2^{*}}$, Rizki Rahfan Abadi Siregarc,3 \\ abc Universitas Lampung, Jalan Prof. Dr. Ir. Sumantri Brojonegoro Bandar Lampung, 35141, Indonesia \\ ${ }^{1}$ ali.imron@fkip.unila.ac.id; ${ }^{2}$ yusuf.perdana@fkip.unila.ac.id; ${ }^{3}$ rizkyrahfan@gmail.com \\ ${ }^{*}$ Corresponding Author
}

\begin{tabular}{ll}
\hline INFO ARTIKEL & ABSTRAK \\
\hline Sejarah Artikel: & Tradisi mangupa merupakan sebuah tradisi yang sampai sekarang \\
Diterima: 3 Februari 2021 & masih dilakukan oleh masyarakat Batak Mandailing. Penelitian ini \\
Direvisi: 2 Maret 2021 & bertujuan untuk mengetahui bagaimana persepsi masyarakat terhadap \\
Disetujui: 20 Maret 2021 & tradisi mangupa, bagaimana implementasi tradisi mangupa di \\
Tersedia Daring: 10 April 2021 & Kelurahan Yukum Jaya, dan bagaimana eksistensi tradisi mangupa di \\
\hline Kata Kunci: & tengah arus modernisasi. Metode dalam penelitian ini adalah metode \\
Batak Mandailing & kualitatif dengan pendekatan deskriptif. Tahapan penelitian ini adalah \\
Eksistensi & pengumpulan data, reduksi data, penyajian data, dan kesimpulan. Hasil \\
Tradisi Mangupa & penelitian dijabarkan sebagai berikut: (1) persepsi masyarakat terhadap \\
& tradisi mangupa adalah ungkapan rasa syukur kepada Tuhan Yang Maha \\
& Esa atas kelancaran dalam suatu acara, (2) implementasi tradisi \\
& mangupa di Kabupaten Lampung Tengah terdapat beberapa tahapan, \\
& mulai dari mengadakan musyawarah, pemberian nasihat dari Dalihan \\
& Na Tolu kepada kedua mempelai, hingga memberikan isi pangupa \\
& sebagai pedoman hidup setelah menikah, dan (3) tradisi mangupa di \\
& Lampung Tengah, khususnya Kelurahan Yukum Jaya masih eksis, \\
& dibuktikan dengan setiap acara perkawinan Batak Mandailing \\
& dipastikan melaksanakan tradisi mangupa. Tradisi mangupa memuat \\
& nilai toleransi dan gotong-royong yang dibuktikan dengan partisipasi \\
& masyarakat umum saat tradisi ini dilakukan.
\end{tabular}

\begin{tabular}{ll}
\hline ABSTRACT \\
Keywords: \\
Batak Mandailing mangupa is a tradition that is still practiced by the Mandailing Batak \\
Existence \\
Mangupa Tradition \\
mangupa tradition, how the implementation of the mangupa tradition in \\
Yukum Jaya Village, and how is the existence of the mangupa Tradition \\
amid modernization. The method in this research is a qualitative with a \\
descriptive approach. The stages of this research are as data collection, \\
data reduction, data presentation, and conclusions. The results of the \\
research are described as follows: (1) public perception of the mangupa \\
tradition is an expression of gratitude to God Almighty for the smooth \\
running of an event. (2) the implementation of the mangupa Tradition in \\
Central Lampung Regency consists of several stages, starting from holding \\
deliberations, giving advice from Dalihan Na Tolu to the bride and groom \\
to providing Pangupa contents as a guide for life after marriage, and the \\
mangupa tradition in Central Lampung, especially Yukum Jaya Village, \\
still exists, as evidenced by the fact that every Batak Mandailing wedding \\
ceremony is ensured to carry out the mangupa tradition. The mangupa \\
tradition contains the values of tolerance and cooperation, which is \\
evidenced by the participation of the general public when this tradition is \\
carried out.
\end{tabular}




\section{Pendahuluan}

Provinsi Lampung merupakan daerah tujuan migrasi masyarakat dari berbagai suku. Beberapa suku tercatat mendiami Provinsi Lampung, di antaranya orang dari suku Semende. Tujuan migrasi dari orang Semende adalah sebagai upaya untuk mencari kehidupan yang lebih baik (Arifin, 2020). Salah satu suku lainnya yakni suku Batak Mandailing.

Batak Mandailing adalah salah satu suku yang berasal dari Kabupaten Mandrin Natal, Tapanuli Selatan, Padang Lawas, Padang Kota Lavas Utara, dan Padangsidempuan, Sumatera Utara. Asal usul nama Mandaling memiliki beragam versi. Mandailing atau Mandahiling bisa berasal kata dari mandala dan hiling atau holing, yang mempunyai arti pusat Negeri Kalinga atau yang akrab dikenal dengan Kalingga. Kalingga berasal dari kata Sanskrit Lingga yang mempunyai arti lelaki dan imbuhan "ka" atau "ha", maka Kalingga atau Halingga mempunya arti kelelakian (Pohan, 2017). Orang Mandailing merantau serta menetap di wilayah Lampung hingga turun temurun. Kedatangan masyarakat Batak Mandailing di Kabupaten Lampung Tengah, tepatnya di Kecamatan Terbanggi Besar, Kelurahan Yukum Jaya secara umum dilatarbelakangi faktor ekonomi, yaitu harapan mendapatkan kesempatan untuk meningkatkan taraf hidup. Ketika orang Batak pindah ke Kabupaten Lampung Tengah, faktor daerah asalnya adalah kurangnya kesempatan kerja dan sulitnya mendapat akses komunikasi dan informasi sedangkan faktor daerah tujuan adalah adanya harapan yang lebih baik yang tidak ditemukan di daerah asal.

Migrasi ini dilakukan oleh salah satu perintis di daerah tersebut. Setelah mendiami daerah tersebut, standar hidup di tempat baru telah meningkat. Kemudian, penduduk asli mendengar berita tentang peningkatan standar hidup. Dengan cara ini, kerabat dan tetangga dari tempat asal akan berkumpul.

Dalam masyarakat yang majemuk seperti Indonesia, fenomena rasial merupakan salah satu spektrum budaya yang senantiasa mengisi dinamika perkembangan berbagai suku bangsa di tanah air. Dalam lingkup sosial-budaya, fakta membuktikan bahwa hal tersebut memegang peranan penting dalam kebudayaan di berbagai daerah, tidak terkecuali suku Batak Mandailing yang mendiami Kelurahan Yukum Jaya, Kabupaten Lampung Tengah, Provinsi Lampung (Sugiyarto, 2017). Suku Batak Mandailing yang mendiami Kabupaten Lampung Tengah, merupakan salah satu masyarakat perantau yang masih memegang teguh adat sebagai pedoman hidup sehari-hari, salah satunya adalah menjaga tradisi mangupa. Tradisi mangupa merupakan suatu kebudayaan yang berupa adat istiadat dari suku Batak Mandailing dalam prosesi perkawinan. Keberadaan produk budaya lisan maupun non lisan ini, pada umumnya memiliki fungsi khusus yang sakral maupun profan dalam kehidupan masyarakat (Rahma et al., 2019).

Manusia memiliki berbagai kebutuhan, seperti kebutuhan biologis, kebutuhan psikologis, kebutuhan sosial, dan kebutuhan rasa aman. Oleh karena itu, manusia membutuhkan dan bergantung satu sama lain, yang menciptakan kelompok yang selalu bersilaturahim sebagai makhluk hidup yang mempunyai kebutuhan biologis, maka manusia mengenal adanya sebuah perkawinan. Melalui perkawinan inilah, seorang akan mengalami perubahan status 
sosial dalam masyarakatnya. Perubahan dari yang berstatus lajang menjadi status berkeluarga (Tri et al., 2020).

Teori kebudayaan menjelaskan bahwa budaya adalah karya masyarakat, rasa dan kreativitas. Karya masyarakat menghasilkan teknologi dan budaya material atau budaya material yang dibutuhkan manusia untuk menguasai lingkungan sekitarnya, sehingga tenaga dan hasil dapat dipertahankan oleh kebutuhan masyarakat (Darwis, 2018). Tradisi mangupa merupakan sentuhan jiwa antara yang di upa dan yang mengupa menganggap cinta sebagai fitrah manusia, sehingga setiap diadakan upacara mangupa tidak ada peserta yang tidak meneteskan air mata. Acara mangupa biasanya dilaksanakan oleh keluarga dekat yang di upa (Mora, Kahanggi, Anak Boru dan Pisang Raut) dan acara ini merupakan salah satu bentuk doa dan permohonan pada Yang Maha Kuasa atau Allah Subhanahu Wata'ala agar yang di upa dan yang mengupa diridhoi dan dirahmati dalam kehidupan mereka. Hal yang disampaikan oleh pengupa kepada yang di upa biasanya berupa nasihat, petuah, dan doa (Brown, 2003).

Sejalan dengan pernyataan tersebut, Aripin (2018) dalam penelitiannya yang berjudul "Mangupa Ditinjau Dari Perspektif Hukum Islam" menyatakan bahwa upacara mangupa merupakan salah satu rangkaian kegiatan masyarakat adat yang bertujuan untuk mengembalikan tondi (roh) ke dalam tubuh yang memiliki fungsi nasihat. Hal ini juga termasuk calon pengantin yang akan membentuk tondi tersebut menjadi calon pengantin baru yang akan berlayar dan mengarungi hidup bersama.

Fakta di lapangan memperlihatkan bahwa budaya dapat saja berubah maupun bergeser. Hal ini tidak terlepas dari adanya faktor-faktor tertentu. Zulmalik (2019) menjelaskan bahwa tradisi mangupa lahiron daganak (kelahiran anak) merupakan tradisi yang telah mendapat pengaruh Islam. Unsurunsur Islam tidak lepas dari tradisi ini, seperti kelahiran bayi, aqiqah, bazanji, sholawatan, dan salat.
Adat istiadat bagi suku Batak merupakan hal yang sakral dan penting untuk dilakukan. Situmorang (2017) menjelaskan bahwa adat istiadat merupakan identitas budaya bagi masyarakat Batak. Adat istiadat ini masih dilaksanakan dalam setiap rangkaian upacara-upacara hingga saat ini. Upacara mangupa yang dilaksanakan masyarakat Batak saat ini berfungsi sebagai sumber dukungan sosial yang didapatkan melalui keluarga, juga termasuk dalihan na tolu.

Tradisi mangupa bagi masyarakat Batak Mandailing yang tinggal di Kabupaten Lampung Tengah merupakan tradisi yang selalu dilakukan apabila terdapat musibah maupun mendapatkan rezeki sebagai doa kepada Tuhan Yang Maha Esa. Menurut Brown (2003) mangupa merupakan salah satu acara paling sakral di dalam acara peradatan suku Batak. Mangupa tidak pernah tertinggal di dalam setiap acara-acara adat yang dilaksanakan. Meskipun banyak imigran dari berbagai suku lain tidak lagi melaksanakan adat istiadat di daerah asalnya, namun tradisi mangupa merupakan salah satu tradisi yang eksis dipertahankan oleh imigran masyarakat Batak Mandailing di Kabupaten Lampung Tengah, khususnya di Kelurahan Yukum Jaya.

Eksistensi tradisi mangupa pada masyarakat Batak Mandailing di Kelurahan Yukum Jaya masih dapat dijumpai hingga saat ini, meskipun terdapat beberapa perubahan tatanan, seperti kerbau yang dapat diganti dengan manuk (ayam) hingga telur karena di Kelurahan Yukum Jaya tidak terdapat kerbau seperti di Sumatera Utara. Eksistensi dalam konteks ini diartikan secara harfiah berarti muncul, timbul, memiliki wujud eksternal, secara singkat dapat diartikan sesuatu yang memiliki wujud, dengan keberadaan bahwa ia merupakan makhluk yang memilih, menciptakan dan mengekspresikan dirinya dengan lingkungannya secara bertanggung jawab (Ekawati, 2015).

Warisan budaya serta kearifan lokal yang ada merupakan bagian penting dalam menumbuhkan dan membangun jati diri 
sebuah bangsa. Budaya memberikan kontribusi besar dalam membentuk karakter bangsa yang tergerus oleh pengaruh global (Sudrajat, 2020). Berdasarkan latar belakang tersebut, fenomena tradisi mangupa di wilayah Yukum Jaya belum pernah diteliti, padahal tradisi ini masih eksis hingga saat ini. Artikel ini bertujuan menganalisis eksistensi tradisi mangupa Batak Mandailing di Kabupaten Lampung Tengah, khususnya Kelurahan Yukum Jaya.

\section{Metode}

Penelitian ini merupakan penelitian kualitatif dengan pendekatan deskriptif. Penelitian kualitatif bertujuan untuk memahami perilaku yang dialami oleh objek penelitian, seperti perilaku, persepsi, motivasi, perilaku, dan lain-lain (Moleong, 2004). Penelitian kualitatif adalah prosedur penelitian yang menghasilkan data deskriptif berupa kata-kata tertulis atau lisan dari orang-orang dan perilaku yang diamati. Sejalan dengan pernyataan tersebut, Nazir (Basri, et al., 2020) berpendapat Penelitian kualitatif adalah rangkaian kegiatan atau proses pengambilan data, proses atau data tersebut merupakan informasi yang wajar tentang kondisi tertentu dari suatu masalah atau aspek kehidupan tertentu.

Data diperoleh peneliti dari wawancara kepada tokoh adat Batak Mandailing, masyarakat Batak Mandailing dan masyarakat Kelurahan Yukum Jaya, Kabupaten Lampung Tengah. Pemilihan nara sumber menggunakan teknik purposive sampling untuk mewakili sampel dari populasi. Teknik pengumpulan data menggunakan teknik wawancara, yakni dengan nara sumber, 1) Bapak Toungku Sutan Ibrahim Harahap selaku tokoh adat Batak Mandailing, 2) Bapak Habibullah Siregar selaku masyarakat Batak Mandailing di Lampung Tengah, dan 3) Ibu Maryati selaku masyarakat suku non Batak Mandailing di Lampung Tengah. Observasi dilakukan di Kelurahan Yukum Jaya sebagai daerah domisili dari masyarakat Batak Mandailing di Lampung Tengah, dan studi kepustakaan yang berkaitan dengan penelitian, jurnal maupun dokumen resmi lainnya dengan penelusuran melalui google scholar maupun Perpustakaan Daerah Provinsi Lampung.

Di sisi lain, peneliti melakukan teknik triangulasi, yakni dengan 3 narasumber yang berbeda melalui wawancara mendalam dari berbagai informan, yaitu dengan mulai dari tokoh adat, masyarakat Batak Mandailing di Lampung Tengah, hingga masyarakat suku non Batak Mandailing sebagai masyarakat umum yang turut membantu pelaksanaan tradisi mangupa. Penelitian dilakukan pada bulan Januari hingga Maret 2021. Teknik analisis data Miles \& Huberman (1992:16) digunakan dalam penelitian ini terdiri dari tiga tahap kegiatan, yaitu pengumpulan data yang terdiri dari reduksi data, mencakup kegiatan mempertajam, mengklasifikasikan, membimbing, menghapus dan mengatur data akhir sehingga kesimpulan akhir dapat ditarik dan diverifikasi, kemudian data tersebut dapat direpresentasikan. Penyajian data dalam penelitian ini dilakukan dengan pemilihan data yang berkaitan dengan latar belakang penelitian, kemudian akan di lakukan pengambilan kesimpulan.

\section{Hasil dan Pembahasan}

\subsection{Persepsi Masyarakat Terhadap Tradisi Mangupa}

Persepsi adalah pengalaman objek, peristiwa atau hubungan yang diperoleh dengan menyimpulkan dan menafsirkan informasi (Jalaludin, 1991). Sejalan dengan pendapat tersebut, Mar'at (1984) berpendapat bahwa persepsi adalah proses mengamati orang dari komponen kognitif. Persepsi dipengaruhi oleh faktor-faktor seperti pengalaman, proses belajar, penglihatan, dan pengetahuan.

Gibson (1986) juga mengungkapkan pandangan yang sama bahwa persepsi juga mencakup kognisi (pengetahuan), termasuk interpretasi objek, tanda, dan orang dari perspektif pengalaman terkait. Persepsi masyarakat akan melahirkan sebuah sikap. Sikap tersebut dapat berbentuk mengikuti tradisi atau meninggalkannya. Lebih jauh mengenai sikap juga diungkapkan Slamet 
Santoso (Risdianawati \& Hanif, 2015) sebagai kepercayaan terhadap individu, kelompok, gagasan atau aktivitas. Persepsi yang merupakan kata lain dari sikap turut serta membentuk karakter seseorang dalam hal kepercayaan. Hal ini masih dipertahankan oleh masyarakat pedesaan. Di Indonesia wilayah pedesaan sebagian besar masih mempertahankan sebuah sistem kepercayaan yang berbasis local wisdom, atau lebih dikenla dengan tradisi. Indonesia dengan latar belakang multietnis, multi budaya, dan multi kultural secara otomatis melahirkan tradisi maupun kebudayaan yang berbeda-beda di setiap daerahnya, khususnya di pedesaan yang masih mempertahankan tradisi-tradisi yang sudah turun-temurun diwariskan dari pendahulunya.

Tradisi merupakan kebiasaan yang dipraktikkan oleh masyarakat dan diwariskan antargenerasi. Tradisi menunjukkan bagaimana anggota masyarakat berperilaku dalam kehidupan sekuler dan terhadap hal-hal supernatural atau religius. Hal yang paling mendasar tentang tradisi adalah adanya informasi yang diwariskan dari generasi ke generasi, baik tertulis maupun lisan (biasanya lisan), karena tanpa informasi tersebut maka tradisi dapat punah. Tradisi yang dimiliki masyarakat bertujuan untuk menjadikan kehidupan manusia kaya akan nilai budaya dan sejarah. Selain itu, tradisi juga akan menciptakan kehidupan yang harmonis. Namun, ini hanya akan tercapai jika manusia menghormati, menghormati dan melaksanakan tradisi dengan benar dan sesuai aturan. Tentu saja tradisi lahir dengan kemunculan manusia di muka Bumi.

Tradisi adalah kata yang sangat familiar yang dapat ditemukan di segala bidang. Tradisi yang digambarkan oleh Esten (1991) merupakan praktik genetik sekelompok orang berdasarkan nilai-nilai budaya masyarakat yang bersangkutan. Sejalan dengan Esten, Soekanto (1987) menyatakan tradisi adalah perbuatan yang diulang-ulang dalam bentuk yang sama. Lebih jauh, Brown (2003) menjelaskan bahwa mangupa merupakan salah satu tradisi atau acara paling sakral di dalam acara peradatan suku Batak dan mangupa tidak pernah tertinggal di dalam setiap acara-acara adat yang dilaksanakan.

Tradisi mangupa menurut Bapak Habibbullah Siregar selaku masyarakat Batak Mandailing merupakan tradisi turuntemurun dari daerah asal yang selalu diadakan di dalam acara-acara tertentu. Adapun peristiwa-peristiwa yang diadakan acara mangupa pada waktu anak laki-laki menikah, anak perempuan menikah, memasuki rumah baru, mendapat anak pertama, orang tua meninggal, suami atau istri meninggal, lepas dari mara bahaya, dan mendapatkan keuntungan atau rezeki yang besar (Siregar, 2021).

Tradisi mangupa di dalam acara pernikahan di Yukum Jaya tidak selengkap di daerah asalnya. Tradisi mangupa dilakukan oleh keluarga terdekat, seperti dalihan na tolu yang mempunyai arti tiga tungku. Tiga tungku tersebut meliput kahanggi (keluarga semarga), anak boru (keluarga dari adik perempuan), dan mora (kelurga dari saudara kandung laki-laki dari ibu).

Sejalan dengan pendapat tersebut, Bapak Tongku Sutan Ibrahim Harahap selaku Tokoh Adat Batak Mandailing di Kabupaten Lampung Tengah, memaparkan dalam tradisi mangupa tentu saja bermacammacam, sesuai kemampuan orang yang akan melaksanakan. Tradisi mangupa merupakan inti dalam acara-acara tertentu, contohnya seperti dalam perkawinan adat Batak Mandailing atau disebut margondang acara di akhiri dengan mengadakan tradisi mangupa yang bertujuan sebagai bentuk rasa syukur masyarakat Batak Mandailing karena sudah melaksanakan perkawinan adat atau margondang tersebut. Teknik mangupa dalam suku Batak Mandailing dibagi menjadi empat jenis pangupa, yaitu pangupa pahoras tondi, pangupa manuk, pangupa kambing, dan pangupa horbo (kerbau) (Harahap, 2021).

Setiap tradisi mempunyai makna yang terkandung, tidak terkecuali di dalam tradisi 
mangupa dalam adat batak mandailing. Dalam tradisi mangupa terdapat sesi pembacaan isi pangupa. Isi pangupa berupa benda natura yang disusun serta mempunyai makna dalam kehidupan berumah tangga. Isi pangupa, yakni sira atau garam, pira manuk na nihobolon (telur ayam yang direbus), manuk na di rengrengan (ayam), udang, ihan adat (ikan adat), bulung ni silalat na di pudun (daun singkong), nasi putih, aek sitiotio (air), bulung ujung (daun pisang), dan anduri atau tampi (tampah). Adanya semua benda natura tersebut dalam acara mangupa, maka akan terlaksana dengan dengan sempurna yakni sesuai pedoman adat Batak Mandailing.

Secara singkat tokoh adat Batak Mandailing, Bapak Tongku Sutan Ibrahim Harahap, mengatakan bahwa mangupa adalah adat orang Batak yang yang dilaksanakan ketika seorang anak laki-laki menikah. Tradisi dilakukan dengan sarana memanjatkan doa untuk keselamatan dunia dan akhirat yang diikuti penyembelihan hewan tertentu. Tingkatan yang pertama adalah dengan memotong kerbau, kedua memotong kambing, dan ketiga dengan memotong ayam dan telur. Apabila mangupa tanpa telur, maka mangupa tidak sah secara adat. Jadi apabila ada orang yang tidak mampu untuk memotong kerbau atau kambing, maka setidaknya dengan telur ayam saja sudah cukup dan dianggap sah (Harahap, 2021).

Tradisi mangupa di Kabupaten Lampung Tengah sangat berbeda dengan mangupa di daerah asalnya sehingga dalam pelaksanaannya masih kurang runut atau masih ada beberapa keterbatasan dalam pelaksanaannya meskipun tidak selengkap di daerah asal. Namun, masyarakat Batak Mandailing di Kabupaten Lampung Tengah tetap tidak meninggalkan tradisinya di tanah perantauan.

Pendapat lain juga diungkapkan oleh masyarakat yang tidak bersuku Batak Mandailing yang tinggal di Kabupaten Lampung Tengah, yakni Ibu Maryati. Ia bersuku Jawa menjelaskan mengenai tradisi mangupa di Kabupaten Lampung Tengah, tepatnya di Kelurahan Yukum Jaya bahwa banyak masyarakat umum yang sangat antusias dalam turut serta membantu proses pelaksanaan tradisi mangupa. Meskipun masyarakat umum tidak diperbolehkan mengikuti jalannya acara, masyarakat umum membantu dalam hal perlengkapan yang akan disediakan dalam melakukan tradisi mangupa. Dikarenakan masyarakat umum tidak diperbolehkan mengikuti mangupa, masyarakat umum kurang memahami secara pasti seperti apa mangupa tersebut. Masyarakat umum hanya mengetahui bahwa tradisi mangupa kurang lebih hampir sama seperti acara syukuran pada umumnya (Mariyati, 2021). Dari persepsi Ibu Mariyati tersebut, berlatar belakang suku Jawa, tampak masyarakat umum sangat mengapresiasi tradisi mangupa yang tetap dipertahankan oleh masyarakat Batak Mandailing di perantauan, khususnya di Kelurahan Yukum Jaya, Kabupaten Lampung Tengah.

Tampak tradisi mangupa mempunyai nilai karakter yang berharga, salah satunya dengan keterbukaan dalam arti siapa pun boleh terlibat untuk membantu, meskipun tidak berlatar belakang suku Batak Mandailing. Meskipun tradisi ini dilakukan untuk masyarakat Batak Mandailing, namun tanpa memandang suku, etnis, dan agama, masyarakat Batak Mandailing di Kelurahan Lampung Tengah sangat terbuka kepada masyarakat umum yang ingin membantu untuk mempersiapkan acara tersebut.

\subsection{Implementasi Tradisi Mangupa Pada Masyarakat Batak Mandailing}

Dalam pelaksanaannya tradisi mangupa dapat dibagi menjadi dua fase, yakni fase persiapan dan fase pelaksanaan. Fase pertama yakni sebelum melaksanakan tradisi mangupa minimal satu hari sebelum pelaksanaan, orang yang punya horja atau hajat mengadakan rapat atau marpokat (bahasa Batak Mandailing). Rapat dilaksanakan untuk membicarakan dan menentukan siapa saja yang akan diikutsertakan dalam tradisi mangupa. 
Berbagai hal tersebut dijabarkan sebagai berikut:

1. Siapa saja golongan Mora

2. Siapa saja golongan Anak Boru

3. Siapa saja golongan Kahanggi

4. Siapa yang akan membacakan Isi Pangupa

5. Siapa saja golongan pisang raut (tidak diwajibkan didalam perantauan)

6. Siapa saja golongan raja-raja adat (tidak diwajibkan di dalam perantauan): Raja nihuta, Raja hatobangon, Raja torbing balok, Raja panusunan bulung, Par alolalok

Hal-hal tersebut merupakan siapa saja yang berhak untuk turut serta melakukan mangupa pada acara tersebut. Fase kedua adalah fase pada saat acara mangupa berlangsung. Fase ini terbagi dalam beberapa langkah berikut:

1. Pangupa diletakkan di depan mempelai dan memastikan semua perlengkapan telah tersedia (seperti tampak pada gambar 1), agar acara dapat segera dimulai dengan dipandu oleh pangetak pangetok (pemandu acara).

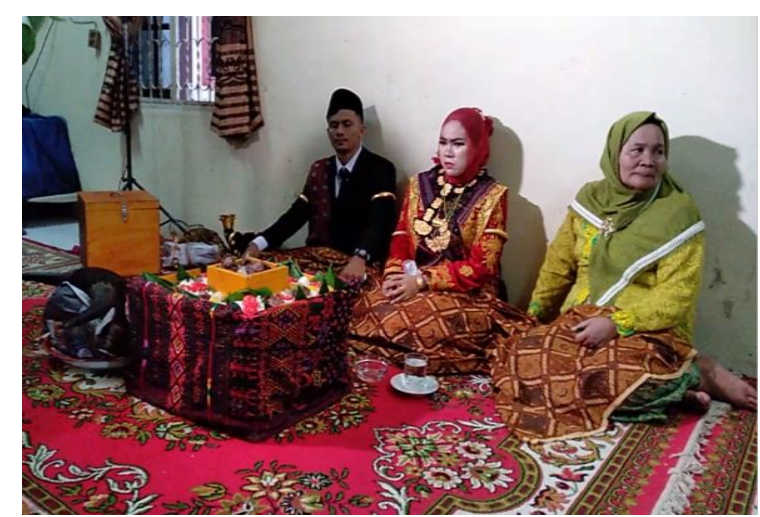

Gambar 1 Proses Persiapan Acara Mangupa (Sumber: Dokumentasi Bapak Baginda Hasundutan Siregar)

Salah seorang anak boru memberikan sirih pada kedua mempelai (tanda acara sudah siap dimulai).

2. Tutup pangupa (daun pisang) dibuka dengan cara digulung dari arah kanan, sedangkan mempelai ke kiri dan sesudah itu diselipkan di bawah tampah sebelah kiri pengantin.

3. Pembicara pada acara mangupa dibagi menjadi 2 golongan, yaitu golongan ibuibu (ina-ina) dan golongan bapak-bapak (ama-ama). Pada prosesi ini golongan ibu-ibu diberi kesempatan untuk memberikan nasihat terlebih dahulu, kemudian dilanjutkan oleh golongan bapak-bapak. Prosesi yang dilakukan inaina terbagi menjadi beberapa golongan, yakni, inatta suripada (ibu mempelai laki-laki), golongan ina, ina kahanggi, golongan ina-ina anak boru, dan golongan ina-ina Mora.

4. Setelah golongan ina-ina selesai, kemudian selanjutnya golongan amaama (bapak-bapak) memberi nasihat kepada mempelai, yakni amatta soripada (suhut sihabolongan), golongan amaama kahanggi, golongan ama-ama anak boru, dan golongan ama-ama mora yang sekaligus menjelaskan arti masingmasing isi pangupa.

Setelah prosesi tersebut selesai, kemudian giliran pengantin menjawab (seperti pada gambar 2). Akan tetapi, sebelum kedua mempelai menjawab, kedua mempelai memakan nasi pangupa, telur dan garam sedikit (suatu bukti bahwa mereka telah menerima petuah dan nasihat dari peserta mangupa), pengantin wanita sebagai penjawab pertama, lalu pengantin pria, selanjutnya setelah selesai masyarakat mengucapkan "horas... horas... horas....", sebagai tanda selesainya acara mangupa pada saat itu.

Acara terakhir yaitu membacakan doa sebagai penutupan oleh orang yang sudah ditentukan atau mahir membacakan doa sesuai martahi (pembentukan panitia) dan setelah itu sudah tidak diperbolehkan lagi ada acara apapun setelah mangupa selesai.

Secara garis besar, tradisi mangupa yang berisikan pemberian nasihat serta doa tersebut dilakukan oleh pengupa. Kata-kata merupakan simbol yang berfungsi mengomunikasikan gagasan pada pihak lain sebagai konsekuensi dari interaksi yang berjalan (Putro, 2020). 


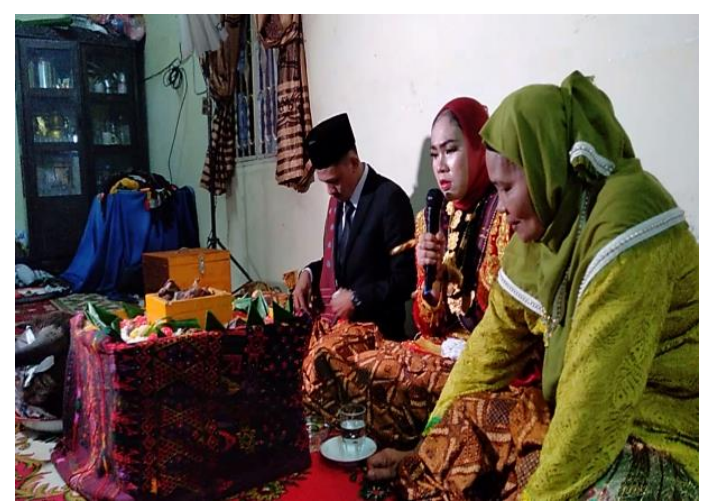

Gambar 2 Mempelai Wanita Menjawab (Sumber: Dokumentasi Bapak Baginda Hasundutan Siregar)

Secara tidak langsung, tradisi ini memuat simbol-simbol sosial. Simbol sosial kemungkinan besar hanya dapat dipahami ataupun dimengerti oleh anggota masyarakat yang memilikinya atau masih menggunakannya. Sebagai media komunikasi atau alat komunikasi yang konkrit, secara verbal simbol tersebut dapat dilihat berdasarkan gerak tubuh dan kata-kata yang termuat dalam bahasa yang diucapkan. Tetapi simbol memainkan peran dalam penggunaan yang lebih bermakna dan konseptual, yakni dalam anggota komunitas sebagai pengikat atau sebagai media integrasi sosial masyarakat yang diwujudkan sebagai sistem nilai atau sistem pranata sosial. Adapun penggunaan simbol melalui proses penjelasan, media komunikasi atau interaksi sosial ini sangat mungkin terjadi. Manusia Akan beradaptasi tidak hanya dengan lingkungannya, tetapi juga akan beradaptasi dengan lingkungan simboliknya (Hendro, 2020).

Kebudayaan sebagai nilai dan sistem pemikiran penting sangat abstrak karena mengembalikan kemampuan dasar manusia yang disebut simbolisasi, yaitu sistem pemikiran yang menekankan atau mengikuti pola berbasis simbol (Agustianto, 2018). Simbol dan budaya sangat berkaitan erat, karena budaya merupakan simbol untuk tujuan-tujuan tertentu yang dilakukan manusia untuk berkomunikasi dengan lingkungan maupun dengan sang pencipta.

\subsection{Eksistensi Tradisi Mangupa di Tengah Arus Modernisasi}

Idrus (Affandi, 1996) mengungkapkan bahwa eksistensi dapat diartikan sebagai makhluk. Adanya masalah adalah efek dari keberadaan atau non-keberadaan manusia. Keberadaan semacam ini menuntut orang lain untuk "memberi" karena tanggapan orang-orang sekitar membuktikan bahwa keberadaannya diakui secara universal oleh masyarakat. Pertanyaan perlunya nilai kelangsungan hidup sangat penting karena membuktikan hasil kerja atau prestasi di lingkungan.

Pendapat lain dikemukakan oleh Abidin (2007), wujud adalah proses dinamis, satu wujud. Hal ini sesuai dengan asal mula kata eksistensi yaitu exsistere yang berarti transendensi atau mengatasi. Oleh karena itu, keberadaannya tidaklah kaku dan stagnan, melainkan fleksibel atau lunak, dan mengalami perkembangan atau kemunduran, tergantung kemampuannya dalam proses mewujudkan potensinya.

Proses modernisasi sosial dan budaya menyebabkan melonggarnya hubungan tradisional dan digantikan oleh hubungan rasional (Widyatwati, 2019). Suatu tantangan tersendiri bagi masyarakat Batak Mandailing dalam menjaga eksistensi tradisi mangupa di tengah modernisasi.

Tongku Sutan Ibrahim Harahap selaku tokoh adat Batak Mandailing di Kabupaten Lampung Tengah menyatakan bahwa eksistensi tradisi mangupa di Kabupaten Lampung Tengah secara luas masih kurang optimal, khususnya oleh masyarakat umum. Seperti halnya masyarakat umum mengetahui bahwa tradisi mangupa seperti acara syukuran, namun sebaliknya masyarakat umum tidak tahu bahwa syukuran bagi masyarakat Batak Mandailing disebut tradisi mangupa. Melalui tradisi ini terdapat hal yang dapat dipetik dalam proses mangupa, yakni masyarakat umum atau dapat dikatakan 
non Batak Mandailing bersedia untuk membantu mempersiapkan perlengkapan yang akan dibutuhkan. Jadi masyarakat secara luas masih kurang begitu paham mengenai tradisi mangupa tetapi keberadaan tradisi mangupa diketahui keberadaannya oleh masyarakat umum. Bahkan, eksistensi mangupa tidak lekang oleh modernitas yang sekarang ini berkembang di tengah-tengah masyarakat.

Bagi masyarakat Batak Mandailing di Kabupaten Lampung Tengah, melaksanakan mangupa dalam sebuah acara pernikahan tentu merupakan tradisi yang wajib bagi anaknya. Namun, untuk tradisi mangupa dalam hal lain, seperti memasuki rumah baru, mendapat anak pertama, baru lepas dari mara bahaya, dan lain sebagainya tergantung pada individu masing-masing untuk mau atau tidak melaksanakannya. Jadi dapat dikatakan selama ini belum ada yang meninggalkan mangupa dalam prosesi pernikahan dalam adat Batak Mandailing. Salah satu faktornya adalah merasa kurang lengkap jika tidak menjalankan tradisi tersebut.

Bagi masyarakat Batak Mandailing yang memegang erat adat wajib untuk melaksanakan tradisi ini, meskipun tidak di daerah asalnya. Jika terdapat masyarakat Batak Mandailing yang tidak mau melaksanakan tradisinya dapat dikatakan sudah tidak lagi memegang teguh tradisi nenek moyangnya. Masyarakat seperti ini dapat dikatakan durhaka terhadap leluhurnya, dan untuk tindak lanjut yang akan dilakukan yaitu dikeluarkan dari perkumpulan Batak Mandaling yang diikuti oleh orang tersebut. Ini merupakan salah satu konsekuensi yang didapatkan jika masyarakat Batak Mandailing tidak melakukan mangupa dalam pernikahan.

Hal senada diungkapkan oleh Listiani (2014) bahwa setiap upacara haruslah dilaksanakan sesuai dengan agama dan adat yang berlaku di masing-masing daerah. Hal ini karena pelaksanaan tradisi antara daerah satu dengan daerah lainnya berbeda-beda, baik dilihat dari adatistiadat, agama, dan kepercayaan. Budaya lokal yang bermuatan nilai-nilai gotong royong, toleransi dan tanggung jawab, terbukti dapat meningkatkan kesadaran nasionalisme, karena selain menjunjung tinggi kerukunan masyarakat, budaya juga dapat menjauhkan manusia dari konflik, terutama konflik-konflik yang bermuatan kultural. Budaya lokal juga dapat menjadi tempat bertemunya anggota masyarakat dari berbagai latar belakang, seperti perbedaan status sosial, ras, agama, ideologi, dan politik (Rika \& Kholidah, 2019).

Kebudayaan bersifat dinamis dan dapat tumbuh dan berkembang seiring dengan perubahan zaman karena kebudayaan dibangun dan direkonstruksi oleh manusia. Namun, beberapa budaya tidak dapat diubah. Koentjaraningrat (Larasati, 2018) membagi budaya menjadi dua bentuk, yaitu fisik dan non fisik. Budaya yang berwujud fisik akan sulit diubah maupun mengalami perubahan. Contoh budaya fisik adalah candi dan prasasti, sedangkan budaya non-fisik berupa pikiran atau ide dan aktivitas manusia yang senantiasa dapat berubah dan beradaptasi dengan latar belakang zaman atau berubah mengikuti zaman. Sebaliknya budaya non fisik mempunyai keterkaitan dengan modernisasi. Dengan kata lain bersifat dinamis dan dapat berubah sesuai waktu atau zaman.

Tradisi mangupa terbukti eksis sesuai dengan perkembangan zaman. Di era modern tradisi mangupa tetap dilestarikan oleh masyarakat Batak Mandailing dengan menyesuaikan beberapa hal. Contoh yang terlihat pada tradisi mangupa di Kelurahan Yukum Jaya tersebut adalah masyarakat Batak Mandailing tidak mewajibkan kerbau sebagai salah satu 
perlengkapannya. Kerbau dapat diganti dengan manuk (ayam) hingga telur guna meringankan masyarakat untuk melakukan tradisi ini, mengingat tidak semua masyarakat mampu membeli kerbau. Selain itu di Kelurahan Yukum Jaya tidak terdapat kerbau seperti di Sumatera Utara yang merupakan tempat lahirnya tradisi ini. Dalam fleksibilitas perlengkapan dari kerbau hingga telur dapat terlihat budaya non fisik berupa tradisi ini berkembang sesuai arus modernisasi yang ada, serta meringankan masyarakat yang melestarikannya dengan pertimbangan strata-strata sosial yang ada di masyarakat batak mandailing di Kelurahan Yukum Jaya, Provinsi Lampung.

\section{Kesimpulan}

Tradisi mangupa bertujuan sebagai ungkapan rasa syukur masyarakat Batak Mandailing kepada Tuhan Yang Maha Esa karena sudah diberikan kelancaran dalam melaksanakan horja atau hajat perkawinan. mangupa merupakan adat istiadat yang wajib dilakukan bagi masyarakat Batak Mandailing dimana pun mereka berada, meskipun dilakukan dengan beberapa perubahan-perubahan tertentu. Pelaksanaan tradisi mangupa intinya adalah pemberian nasihat dari dalihan na tolu (kahanggi, anak boru, dan mora) kepada mempelai pria dan wanita dan juga memberikan makna isi pangupa sebagai pedoman hidup setelah menikah, sehingga bisa membentuk rumah tangga yang damai dan sesaui dengan keinginan oleh leluhur mereka. Eksistensi mangupa masih kurang optimal. Sebagai contoh dalam masyarakat umum (bukan Batak Mandailing) hanya sekadar mengetahui bahwa tradisi mangupa itu sebagai acara syukuran, namun masyarakat secara luas tidak tahu bahwa acara tersebut bagi masyarakat Batak Mandailing bernama tradisi mangupa. Sisi lain dalam eksistensi mangupa tersebut terlihat pada saat acara berlangsung terdapat rasa gotong-royong yang erat. Hal ini dibuktikan keterlibatan masyarakat umum untuk membantu menyiapkan perlengkapan yang dibutuhkan pada tradisi tersebut. Eksistensi tradisi mangupa dapat terlihat secara nyata ditengah arus globalisasi, yaitu masyarakat Batak Mandailing memegang teguh adat istiadat sebagai identitas mereka dimana pun keberadaannya, termasuk di Provinsi Lampung, khususnya Kelurahan Yukum Jaya.

\section{Daftar Pustaka}

Abidin, Z. (2007). Analisis Eksistensial. Jakarta: PT. Raja Grafindo Persada.

Affandi, I. (1996). "Mengenai Kepeloporan Organisasi

Kemasyarakatan Pemuda dalam Pendidikan Politik". Disertasi. Fakultas Pendidikan Ilmu Pengetahuan Sosial. Jurusan Pendidikan Imu Pengetahuan Sosial. Universitas Pendidikan Indonesia. Bandung

Agustianto, A. (2018). Makna Simbol Dalam Kebudayaan Manusia. Jurnal Ilmu Budaya, 8(1), 1-63. https://doi.org/10.31849/jib.v8i1.101 7

Arifin, Z. (2020). Harte Dan Tungguan: Redefinisi Adat Tunggu Tubang Pada Komunitas Semende Migran. Jurnal Masyarakat Dan Budaya, 22(2), 3144.

https://doi.org/10.14203/jmb.v22i2.8 87

Aripin, M. (2018). Mangupa Ditinjau Dari Perspektif Hukum Islam. Jurnal ElQanuniy: Jurnal Ilmu-Ilmu Kesyariahan Dan Pranata Sosial, 4(1), 48-60. https://doi.org/10.24952/elqonuniy.v4i1.1826

Basri, M., Arif, S., Perdana, Y., \& Sumargono, S. (2020). Nilai-Nilai Sejarah Berbasis Local Wisdom Situs Batu Berak Sebagai Sumber 
Pembelajaran Sejarah. Gulawentah:Jurnal Studi Sosial, 5(2), 125.

https://doi.org/10.25273/gulawentah. v5i2.7241

Brown, H. (2003). Adat Peradatan Suku Batak.

Darwis, R. (2018). Tradisi Ngaruwat Bumi Dalam Kehidupan Masyarakat (Studi Deskriptif Kampung Cihideung Girang Desa Sukakerti Kecamatan Cisalak Kabupaten Subang). Religious: Jurnal Studi AgamaAgama Dan Lintas Budaya, 2(1), 75. https://doi.org/10.15575/rjsalb.v2i1.2 361

Listiani, N. P. D. (2014). Eksistensi Tradisi Adat Ngoncang Di Desa Pegadungan, Kecamatan Sukasada, Kabupaten Buleleng Ditinjau Dari Segi NilaiNilai Sosial Budaya. Pendidikan Kewarganegaraan Undiksha, 2(2), 111.

http://dx.doi.org/10.23887/jpku.v2i2. 1123

Ekawati, D. (2015). Eksistensialisme. Jurnal Tarbawiyah, 10(2), 75-84. https://ejournal.metrouniv.ac.id/index .php/tarbawiyah/article/download/42 $7 / 228$

Putro, Z. A. E. (2020). Reformulasi Identitas Buddha Jawi Wisnu dan Sam Kaw Hwee Ke Dalam Buddhayana di Lampung Reformulating Identity of Buddha Jawi Wisnu and Sam Kaw Hwee Into Buddhayana in Lampung. Jurnal Masyarakat Dan Budaya, 22(2), 1729.

https://doi.org/10.14203/jmb.v22i2.1 007

Esten, M. (1991). Kesustraan: pengantar Teori sejarah. Angkasa.

Gibson. (1986). The Ecologikal Approach to Visual Perception. Prentice Hall International, Inc.
Harahap, T. S. I. (2021). Wawancara.

Hendro, E. P. (2020). Simbol : Arti , Fungsi , dan Implikasi Metodologisnya. Endogami: Jurnal Ilmiah Kajian Antropologi, 3(2), 158-165. https://doi.org/10.14710/endogami.3. 2.158-165

Jalaludin, R. (1991). Psikologi Pendidikan. Ghalia Indonesia.

Larasati, D. (2018). Globalisasi Budaya dan Identitas: Pengaruh dan Eksistensi Hallyu (KoreanWave) versus Westernisasi di Indonesia. Jurnal Hubungan Internasional, 1, 109-120.

http://dx.doi.org/10.20473/jhi.v11i1. 8749

Mar'at. (1984). Psikologi Sosial. Gramedia Pustaka Utama.

Mariyati. (2021). Wawancara.

Miles, B. M., \& Huberman, M. (1992). Analisis Data Kualitatif Buku Sumber Tentang Metode-metode Baru. Jakarta: UIP.

Moleong, L. J. (2004). Metodologi Penelitian Kualitatif. PT. Remaja Rosdakarya.

Pohan, M. (2017). Perkawinan semarga masyarakat migran batak mandailing di yogyakarta. Al-Ahwal: Jurnal Hukum Keluarga Islam, 10(2), 134147.https://doi.org/10.14421/ahwal.2 017.10202

Rahma, D., Berlian, V., \& Novitasari, S. (2019). Resepsi Ikatan Keluarga Banyuwangi Terhadap Mantra Sabuk Mangir. Jurnal Satwika : Kajian Ilmu Budaya Dan Perubahan Sosial, 3(2), 103-110. https://doi.org/10.22219 /satwika.v3i2

Rika, N., \& Kholidah, J. (2019). Eksistensi Budaya Lokal Sebagai Penguat Nasionalisme. Seminar Nasional Penelitian Dan Pengabdian 
Masyarakat-LP4MP Universitas Islam Majapahit, 168-174.

Risdianawati, L. F., \& Hanif, M. (2015). Sikap Masyarakat Terhadap Pelaksanaan Upacara Kelahiran Adat Jawa Tahun 2009-2014 (Studi Di Desa Bringin Kecamatan Kauman Kabupaten Ponorogo). Agastya: Jurnal Sejarah Dan Pembelajarannya, $5(01), \quad 30$. https://doi.org/10.25273/ajsp.v5i01.8 95

Siregar, H. (2021). Wawancara.

Situmorang, R. (2017). "Mangupa Sebagai Bentuk Dukungan Sosial: Studi indigenous Terhadap Etnis Batak". Skripsi. Fakultas Psikologi. Jurusan Psikologi. Universitas Sumatera Utara.

Soekanto, S. (1987). Sosiologi Hukum dalam Masyarakat. Rajawali.

Sudrajat, A. R. (2020). Pewarisan NilaiNilai Kearifan Lokal Kalosara dalam Pembelajaran Sejarah Untuk Membangun Karakter Siswa. Historia: Jurnal Program Studi Pendidikan Sejarah, 8(1). http://dx.doi.org/10.24127/hj.v8i1.22 54

Sugiyarto. (2017). Menyimak ( Kembali ) Integrasi Budaya di Tanah Batak Toba. Endogami: Jurnal Ilmiah Kajian Antropologi, 1(1), 34-41. https://doi.org/10.14710/endogami.1. $1.34-41$

Tri, J., Eka, D., \& Lestari, G. (2020). Tradisi Ruwatan Jawa Pada Masyarakat Desa Pulungdowo Malang. Jurnal Satwika : Kajian Ilmu Budaya Dan Perubahan Sosial,4(2), 94-105.

https://doi.org/10.22219/satwika.v4i2 .14245

Widyatwati, K. M. (2019). Merti Desa: Eksistensi Tradisi Masyarakat Agraris
Di Kabupaten Semarang. Jantra: Jurnal Sejarah Dan Budaya., 14(1), 9-

14.http://jantra.kemdikbud.go.id/inde x.php/jantra/article/download/78/53

Zulmalik. (2019). "Tradisi mangupa lahiron daganak (kelahiran anak) pada masyarakat batak mandailing di Kampung Pecin, Desa Sekijang, Kecamatan Tapung Hilir, Kabupaten Kampar, Provinsi Riau". Skripsi. Fakultas Adab dan Ilmu Budaya Universitas Islam Negeri Sunan Kalijaga Yogyakarta. 